\title{
Experience and Prospect of Trade War Between China and the United States
}

\begin{abstract}
Jiaheng Deng
Law School, University of Edinburgh, Edinburgh, UK

*Corresponding author. Email: shilishuang@cas-harbour.org

ABSTRACT

After the initial opening, development and friction, trade between China and US has now escalated into a trade war. After the wars of 301 and 232, China and the United States realized that only cooperation could conform to the trend of international economic development, so they sought solutions through bilateral agreements. Firstly, this paper reviews the history of trade between China and the United States to illustrate the potential of cooperation between this two country; Secondly, by analyzing the bilateral agreements signed, it points out that China and the United States have begun to cooperate to solve trade problems, and the economic and trade relations between the two countries have eased; Finally, this paper gives suggestions on how to better promote the development of Sino US trade relations. China and the United States should, in line with the trend of globalization, shoulder their respective responsibilities as big powers and make joint efforts for world development.
\end{abstract}

Keywords: Trade between China and the United States, bilateral agreements, WTO dispute settlement mechanism

\section{INTRODUCTION}

It has been 40 years since the establishment of diplomatic relations between China and the United States. In the past 40 years, although there were some small trade conflicts between the two countries, they soon subsided. From the past trade exchanges between the two countries, it is not difficult to find that the development of trade between China and US has its own characteristics. The United States is the most economically developed country in the world, while China is the fastest growing country. Since the establishment of trade relations, the trade between the two countries has been developing rapidly and the scale of trade has also expanded rapidly. And with the improvement of China's science and technology level and the adjustment and upgrading of industrial structure, the commodity structure of two country's trade has gradually changed. The proportion of capital and technology intensive goods in the trade of manufactured goods is rising, while the proportion of labor-intensive goods is declining. However, with the comprehensive and in-depth development of two country's trade relations, trade friction between China and the United States has become increasingly frequent and intensified. From March 2018, the "232 war" and the "301 war" broke out between China and the United States one after another. These two trade conflicts have had a huge impact on the relations of China and the United States [3].

This paper focuses on the compromise and efforts that both made by China and the USA to end the trade war after the outbreak of the trade war. The second chapter analysis solutions to find specific experience to deal with the trade war. The third chapter is to expand the diversity of trade dispute settlement between China and the United States, and provide possible methods for the continuous development of SinoUS trade, so as to prevent large-scale trade conflicts in the future. This paper mainly analyzes the existing dispute settlement methods and explores more dispute settlement methods.

\section{THE EXPERIENCES FROM THE TRADE CONFLICT SOLUTION}

The bilateral trade between China and the United States got off to a good start in. From January to February, the trade volume between the two countries increased by $81.3 \%$ compared with the same period in 2020 , reaching about 109.8 billion US dollars, which is the largest increase among all China's trading partners. Among them, China's exports to the United States increased by $87.3 \%$, reaching US $\$ 80.53$ billion. In the 
same period, US merchandise exports to China were 29.27 billion yuan, an increase of $66.4 \%$ over the same period in 2020.Such trade exchanges between China and the United States in the post epidemic era are undoubtedly the result of the joint efforts of the two countries [12].

\subsection{American efforts}

In January 2020, the U.S. Treasury Department released a semi annual report on the macroeconomic and foreign exchange policies of major U.S. trading partners. The report removed the identification of China as a "currency manipulator". From the beginning of this measure, the United States began to realize that efforts to repair the relationship with China, an important trading partner, are crucial. Two days after the United States made this move, representatives of China and the United States signed the first phase of the Sino US economic and trade agreement in the White House, declaring that the two-year "trade war" between China and the United States has come to an end temporarily. The agreement signed in the White House shows the willingness of the United States to give up its previous tough stance of binary opposition. Since Biden's administration took office, his team has made efforts to restore Sino US trade relations in finance, technology, environment and personnel appointment.

First of all, in finance, Biden government has changed the practice of using tariff weapon without lower limit in trump period and replaced it with multi rational means of checks and balances. The Biden administration plans to conduct an inter departmental review of Trump's measures, including imposing trade tariffs on Chinese goods and removing certain Chinese companies from the list. The US side agreed to strengthen communication, control differences and push bilateral trade relations back to the track of cooperation. This shows that during Biden's term of office, the trade friction between China and the United States will be a "competition of rules" rather than a "competition of tariffs". As a result, the trade friction between China and the United States will not turn into a very fierce conflict, and the financial relationship between China and the United States will continue to present a situation of "fighting but not breaking".

Secondly, in terms of science and technology, the United States did not continue the practice of generalizing national security in the trump era, no longer expel scientific and technological talents, and cancelled the policy of tightening the visa for international students in the stem field. These changes will help to restore some of the exchanges between China and the United States in science, technology and humanities.

Thirdly, in terms of environment, China and the United States jointly promoted the signing of the Paris
Agreement during the Obama administration. After the farce of Trump's administration, Biden signed 17 executive orders on the first day of his inauguration. These executive orders focused on solving the "new crown crisis, climate crisis" and other issues, including rejoining the Paris climate agreement.

At the same time, the US government has also made efforts in personnel appointment to ease Sino US trade. Biden appointed Kurt Campbell and Lola Rosenberg as assistant to the National Security Council for Asia Pacific Affairs and senior director of China affairs respectively. He hoped that the government departments could reach a consensus on China relations, balance the strength of various factions in the party, and pull China US relations back from the brink, so as to form a new situation of moderate confrontation and cooperation in competition.

It can be seen from the above efforts made by the United States that the United States hopes to break the deadlock in relations with China and will more actively promote cooperation between the two countries in all aspects.

\subsection{Chinese efforts}

There is no doubt that the successful signing of the first stage of Sino US economic and trade agreement is the result of Sino US joint consultation. China has also responded positively to the implementation of the agreement. According to the data of Peterson Institute of international economics, according to the 2017 US export benchmark to China, after the signing of the 2020 agreement, the actual purchase volume of US \$94 billion has been completed. China has achieved $59.12 \%$ of the agreed procurement target [13]. Among them, the actual purchase amount of manufactured goods is 57 billion US dollars, and China has achieved $57.34 \%$ of the purchase target; The actual purchase number of agricultural products is 27.3 billion US dollars, and China has achieved $81.74 \%$ of the purchase target; The purchase number of other products is US $\$ 30.7$ billion, and China has achieved $88.47 \%$ of the promised purchase target [13]. According to the data, China has almost fulfilled the responsibilities promised in the first phase of the agreement, and the U.S. authorities have also recognized Chinese efforts in this regard[13].

In terms of service trade, China has further expanded the opening up of financial service industry, and this concession of China has made wall street of the United States gain a lot. JPMorgan Chase Bank has set up its own securities company and futures company in China; Morgenstein set up its own securities company in China; Goldman Sachs transformed Gaohua securities company into its wholly-owned securities company; Citibank has been granted an asset custody license to provide services to mutual funds and private funds in China [11]. 
On the protection of intellectual property rights, in April 2020, the people's Court of Pudong New Area in Shanghai ruled that the famous American sporting goods manufacturer New Balance won a noticeable trademark infringement lawsuit, and New Balance received a compensation of 1.5 million US dollars. The result of the case shows that China is actively implementing the provisions on intellectual property protection in the economic and trade agreement.

In terms of energy, the super factory of Tesla electric vehicles is still expanding in Shanghai, which shows that China and the United States have great potential to jointly lead the energy revolution, and China is willing to expand cooperation space with the United States in the field of climate and environment. This sign also further indicates that the consensus on green development may become a new link to regulate Sino US relations.

\section{A MORE COMPREHENSIVE SOLUTION TO SINO US TRADE DISPUTES}

\subsection{Promotion of the operation and reform of WTO Dispute Settlement Body}

After the Second World War, people realized that international trade must be carried out through a standardized multilateral trade system, so the WTO was established to regulate international trade and prevent the outbreak of large-scale trade war. The dispute settlement mechanism of WTO is an indispensable part of WTO. The purpose of its establishment is to enable its members to correct the trade behaviors inconsistent with WTO regulations within a reasonable period of time and make them conform to WTO trade rules 《The understanding on dispute settlement rules and procedures (DSU) emphasizes in its Article 23 that if any WTO Member considers that his rights are infringed or his interests are lost by other members, the parties must resort to the multilateral dispute settlement mechanism within the WTO system.[10]

The call for reform of the existing WTO dispute settlement mechanism has existed for decades. Especially today's trade war reflects a series of defects of WTO dispute settlement mechanism. First of all, the WTO has set up many exceptions, but these Provisions are very vague, leading to the circumvention of dispute settlement procedures. For example, in this trade war, the United States claimed that its measures met the "security exception" clause of Article 21 of GATT. Such provisions lead to the parties directly resort to private remedies outside the procedure when the procedure starts, which is difficult to prevent the further escalation of trade disputes. Secondly, the dispute settlement mechanism of WTO lacks necessary protective measures, which makes it difficult to safeguard the interests of the performing party. The remedy measures of WTO are non punitive and anticipatory. The purpose of withdrawing the non-conforming measures, compensating and suspending the concession obligations is to protect the equal trade opportunities of both parties, not to carry out retrospective punishment to recover the damage caused by the illegal measures to the performing country. This leads to the lack of deterrent power in the relief of the corresponding rules of WTO. In practice, the defaulting country can use its own economic advantages to cause sustained trade harm to the actual performing country. Thirdly, consensus mechanism in DSU will create deadlock in dispute settlement. According to the DSU, the DSB shall appoint members of the Appellate Body for a term of four years, each of whom may be re elected once. However, the decision on dispute settlement should be made by consensus. Under the background of Sino US trade war, the Appellate Body of WTO has been suspended in 2019. This is mainly because under the existing mechanism, WTO members can organize the selection of appellate body members through one vote against, so as to achieve the political goal of manipulating the appellate body. The suspension of WTO Appellate Body is very disadvantageous to the settlement of trade conflicts under the multilateral trade mechanism. Therefore, China and the United States can promote the better operation of the dispute settlement mechanism through the following efforts.

In order to solve trade disputes within the framework of WTO, the dispute settlement mechanism of WTO can be improved in the following aspects. First of all, we can define the meaning of "exceptional provisions" and determine a special evaluation mechanism. From the perspective of the Sino US trade war, the "security exception" in Article 21 of GATT may become a means for WTO members to evade the dispute settlement mechanism, which will form an improper incentive mechanism for trade protectionism and further worsen the international free trade environment. Therefore, on the one hand, it is necessary to further explain the contents of the agreement that affect the jurisdiction of DSB, such as "affecting national security", so as to clarify its use standard in practice; On the other hand, it is necessary to establish a special evaluation mechanism according to the applicable standards of the exception provisions. Only in this way can we truly establish the credibility of DSB as a national trade dispute settlement body, and then prevent the further escalation of trade disputes between different countries in the world.

Secondly, necessary procedural preservation measures can be established to safeguard the interests of the performing state. The international free trade environment depends not only on the conscious maintenance of each country, but also on the outcome of trade dispute adjudication to form a correct incentive mechanism for the whole international community. Therefore, the WTO can draw lessons from the Interim 
Measures of protection of the International Court of justice to prevent the ruling of DSB from losing its significance due to the unilateral activities of one party. The applicable standards of protective measures mainly include whether irreparable damage may or will happen. The content of preservation measures should include property preservation and evidence preservation, and can be set up in two forms: starting according to DSB authority and starting according to the application of the parties. Finally, a new open appellate body can be established in addition to the existing appellate body. Under this framework, the panel procedure is not affected. However, compared with the original appellate body, the new appellate body does not need the full participation of all members. WTO members who accept the proposal can automatically choose to join. The elected members will jointly elect seven new members of the appellate body. Of course, the new appellate body can only decide the disputes between the participating members of the new Appellate Body agreement. When the dispute involves at least one non participating member of the new appellate body, it can only be heard by the original appellate body. When the original appellate body fails to operate, the existing WTO members either choose to give up the dispute settlement in the WTO or join the new dispute settlement mechanism.

Although Sino US trade disputes have made some progress by way of agreement, if they can be settled through the dispute settlement mechanism of WTO, it will undoubtedly play an exemplary role in dealing with trade issues for all countries in the world, which is more conducive to the standardization of the world trade order.

\subsection{Improvement of the domestic trade laws}

In order to deal with the possible trade war in the future, it is also essential to enhance Chinese ability to resolve disputes.

First of all, China can deeply study the foreign trade law of the United States. When studying American trade law, we should pay special attention to the differences between the United States and China. For example, when there is a conflict between domestic laws and international treaties, which legal provisions shall prevail. Chinese rule is that international treaties take precedence, while the United States has the opposite rule. According to the constitution of the United States, the legislation of Congress and international treaties are the supreme laws of the constitution of the United States. If the status of the two is equal, and if the priority is concerned, the general principle is that the new law is superior to the old law. The existence of this provision makes the U.S. law as the main basis in the settlement of Sino US trade disputes, that is, the U.S. foreign trade law. Therefore, it is not enough for China to study WTO regulations to safeguard Chinese interests when settling
Sino US trade disputes. At the same time, the United States is a highly legalized country, and its measures against China will be carried out in strict accordance with the relevant laws of American domestic law. When China wants to take relief measures, it must also be carried out in accordance with American domestic law. In addition, Chinese enterprises should strictly regulate their operation in accordance with the requirements of American domestic law, which can effectively avoid more disputes between the two countries.

Secondly, China can improve its legal rules of international trade. WTO member states usually implement WTO rules indirectly through domestic legislation, and China is no exception. In order to adapt to the rules of WTO, although China has issued antidumping regulations, anti subsidy regulations and other laws, these regulations still have some defects and loopholes compared with the rules of WTO. For example, the WTO's "anti dumping agreement" stipulates that if the export price is considered to be unreliable, then the price should be excluded and other ways should be adopted to calculate the appropriate export price. However, this provision is not found in Chinese anti dumping regulations. Then, in order to determine a reasonable price in future disputes, China should add the WTO provisions into its own laws.

Finally, China can enhance its ability to resolve Sino US trade disputes. China can strive to cultivate highquality WTO law professionals. At present, when China is settling international disputes, most of the time it employs lawyers from the United States, the United Kingdom and other countries. In doing so, not only the agency costs are high, but also the Ministry of Commerce generally comes forward to solve them, which makes economic disputes easily turn into political disputes. Therefore, in order to better deal with possible trade disputes between China and the United States in the future, China needs to cultivate a group of professionals to deal with trade disputes between China and the United States.

In addition, it is necessary for China to establish a special Sino US trade dispute research institution and establish and improve the Sino US trade dispute prevention mechanism. China can include the existing disputes between China and the United States in the scope of the agency's research, and the agency can also undertake the consulting responsibility of Chinese enterprises for the laws, regulations or policy requirements of U.S. export trade. According to the Sino US dispute prevention mechanism, the agency can collect and process the Sino US trade information, and finally form a report to be published to relevant industries in China, so that enterprises can fully understand the changes of the latest US trade information, so as to deal with Sino US trade disputes. 


\subsection{Objective understanding of today' $s$ world pattern}

For the development of today's world, both China and the United States should have such a consensus: the development of an open global market economy is an irresistible world trend, and the nation-state should adapt to this development, at least more firmly safeguard and not destroy the international multilateral rules and the existing international order of globalization. [8]

For China, it is unacceptable to assume that China will enjoy the treatment of developing countries and regions until its per capita income catches up with that of developed countries and should not bear more international responsibilities. As a rising country, it is wrong to assume that what developing countries and regions can do, what policies and strategies they can adopt, and China can do as well. As an emerging power, on the one hand, China is vigorously carrying out foreign investment, expanding foreign trade exchanges, and even promoting the establishment of some international organizational mechanisms; On the other hand, Chinese domestic market should be more open. The idea that they can enjoy the preferential treatment of developing countries and regions all the time, or even forever, without equal liberalization is fanciful.

In the context of globalization, to build a new type of Sino US trade relations requires both countries to adjust their minds objectively and calmly. The United Statesshould constructively interpret the rise of China and the adjustment of Chinese foreign exchanges. Both sides should avoid using their own standards to demand and judge each other, and seek and build a common and acceptable market model.

\section{CONCLUSION}

As the world's largest economies, China and the United States share many common interests, The two countries depend on each other.Both sides must understand that the United States cannot solve international hot issues without China, and China cannot play a greater role in international affairs without the United States. In order to avoid falling into the Thucydides trap, both sides should maintain a modest and prudent attitude and strengthen dialogue and understanding. We expect the two sides to assume the responsibilities of big powers and jointly promote the development of the global economy under the framework of bilateral agreements and multilateral trade rules in the future.

\section{REFERENCES}

[1] A. Kiss, D. Shelton. Guide to International Environment Law. Martiuns Nijhoff Publishers. 2007.
[2] N.S. Malcolm. International Law (Two Volumes). Peking University Press. 2005.

[3] I. Brownlie. Principles of Public International Law. Law Press.China. 2003.

[4] T.Y. Wang. Introduction to International Law. Peking University Press. 1998.

[5] X.M. Wang. State Obligations to the International Community as a Whole. Law Press. China. 2009.

[6] M. Ragazz. The Concept of International Obligations Erga Omnes. Law Press. China. 2013.

[6] S.Y. Sun. The Obligations of State Parties Under the International Covenant on Civil and Political Rights. Social Sciences Academic Press (China). 2012.

[6] H.W. Liu. On the On the Asymmetry of State Obligations Under the International Covenant on Economic, Social and Cultural Rights. Peking University Press. 2005.

[6] G.P. Rao. On the Relationship Between International Organizations and Law of International Organizations. Peking University Law Journal. 1999 (1).

[6] G.P. Rao. Ontology, Object and Scope: Discussion of the Basic Problems on the Discipline of Law of International Organizations. Chinese Review of International law.

[11] H. Song. International Economic Review. Issue 6. 2019.

[12] F. Ni. International Economic Review. Issue 1. 2021.

[13] G. Yang. International Law Review of Wuhan University. 2018(3). 